"International economic and social determinants of the state economic security: A causal analysis"

\begin{tabular}{|c|c|}
\hline \multirow{5}{*}{ AUTHORS } & Volodymyr Orlov (iD) \\
\hline & Alina Bukhtiarova (D) \\
\hline & $\mathbf{R}$ \\
\hline & Marcin Marczuk (iD) \\
\hline & Mykhaylo Heyenko (D) \\
\hline ARTICLE INFO & $\begin{array}{l}\text { Volodymyr Orlov, Alina Bukhtiarova, Marcin Marczuk and Mykhaylo Heyenko } \\
\text { (2021). International economic and social determinants of the state economic } \\
\text { security: A causal analysis. Problems and Perspectives in Management, 19(4), } \\
\text { 301-310. doi:10.21511/ppm.19(4).2021.24 }\end{array}$ \\
\hline DOI & http://dx.doi.org/10.21511/ppm.19(4).2021.24 \\
\hline RELEASED ON & Tuesday, 23 November 2021 \\
\hline RECEIVED ON & Friday, 01 October 2021 \\
\hline ACCEPTED ON & Friday, 19 November 2021 \\
\hline & $($ (cc) $\overline{E Y}$ \\
\hline LICENSE & $\begin{array}{l}\text { This work is licensed under a Creative Commons Attribution } 4.0 \text { International } \\
\text { License }\end{array}$ \\
\hline JOURNAL & "Problems and Perspectives in Management" \\
\hline ISSN PRINT & $1727-7051$ \\
\hline ISSN ONLINE & $1810-5467$ \\
\hline PUBLISHER & LLC "Consulting Publishing Company "Business Perspectives" \\
\hline FOUNDER & LLC "Consulting Publishing Company "Business Perspectives" \\
\hline & ニニ: \\
\hline NUMBER OF REFERENCES & NUMBER OF FIGURES \\
\hline 32 & 2 \\
\hline
\end{tabular}

(C) The author(s) 2021. This publication is an open access article. 


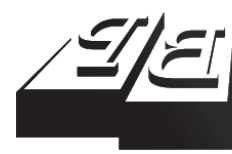

BUSINESS PERSPECTIVES

O

LLC "CPC "Business Perspectives"

Hryhorii Skovoroda lane, 10,

Sumy, 40022, Ukraine

www.businessperspectives.org

Received on: $1^{\text {st }}$ of October, 2021

Accepted on: $19^{\text {th }}$ of November, 2021

Published on: $23^{\text {rd }}$ of November, 2021

(c) Volodymyr Orlov, Alina Bukhtiarova, Marcin Marczuk, Mykhaylo Heyenko, 2021

Volodymyr Orlov, Ph.D. in Economics, First Deputy Head of the Dnipropetrovsk Regional State Administration, Ukraine.

Alina Bukhtiarova, Ph.D. in Economics, Postdoctoral Student, Department of Financial Technologies and Entrepreneurship, Sumy State University, Ukraine. (Corresponding author)

Marcin Marczuk, Dr., Lecturer Institute of Public Administration and Management, University of Economy and Innovation in Lublin, Poland.

Mykhaylo Heyenko, Ph.D in Economics, Associate Professor, Head of Department of Finance, Banking and Insurance, Sumy National Agrarian University, Ukraine.
Volodymyr Orlov (Ukraine), Alina Bukhtiarova (Ukraine), Marcin Marczuk (Poland), Mykhaylo Heyenko (Ukraine)

\section{INTERNATIONAL ECONOMIC AND SOCIAL DETERMINANTS OF THE STATE ECONOMIC SECURITY: A CAUSAL ANALYSIS}

\begin{abstract}
The priority task for ensuring the economic security of a country, which is especially noticeable in the rapidly changing conditions of the contemporary global world, is to forecast challenges and threats. Economic security is one of the necessary conditions for state development, which provides guidelines for making major social and economic decisions. There are a few studies on the determinants of the economic security and no data about security determinants that are required to monitor it. The study aims to identify possible links between leading determinants of the economic security. For this purpose, on the example of Ukraine, causal links between the formation of real GDP (as the leading determinant that characterizes the economic security of the state), 11 determinants that indicate the level of international economic development, and 6 determinants of social development for the period 2014-2020 were determined. With a 5\% level significance, the impact on the volume of real GDP of 14 determinants of state economic security was noted and specific time lags were defined. Besides, the bilateral causal effect and lack of causal connection between individual determinants were mentioned. Findings are helpful for effective public administration. In addition, active measures are needed to combat corruption, shadow and criminal economy, and state protection of domestic producers operating in the military, food, information, and energy security sectors.
\end{abstract}

Keywords

state economic security, GDP, causal analysis, economic development, public administration

JEL Classification G17, C32

\section{INTRODUCTION}

Crisis developments in the world economy, a sharp increase of international economic conflicts, hostile actions of external actors (e.g. sanctions and trade wars) naturally damage the interests of national economies. A revival of interest in theoretical and applied research is related to the economic security of the state. On one hand, digital economy at a current stage of economic and social development expands the possibilities of human development. On the other hand, the transition to a new economic order faces some challenges and contradictions caused by globalization and informatization, which affect all spheres of life and requires a comprehensive approach to national economic security. State economic security is formed due to various determinants, which largely explain differences and features of foreign and domestic policies. An essential task in ensuring the state economic security is its assessment and identification of directions for its strengthening. However, currently, there is a lack of economic research and insufficient attention is paid to the comparative assessment of the economic security.

Economic security affects the effective functioning of the state. In its most general form, an effective state is a state that defends its national 
interests and ensures its national economic security, both in good times and in moments of crisis, and in conditions of unlimited international competition. In practice, one cannot solve any of the tasks facing a modern state without ensuring economic security.

The foundation for strengthening the economic security of a country is the development of production and technological base, national innovation system, increasing the country's investment attractiveness, modernization, development of priority sectors of the national economy, creation and improvement of a business climate.

For a country, it is essential to increase the efficiency of economy regulations to achieve sustainable economic growth and stability of the financial system, its functioning and development, thus increasing and ensuring the economic security of the state.

\section{LITERATURE REVIEW}

The conceptual foundations of economic security take place in conditions of significant uncertainty and are methodologically unsupported to an appropriate extent. Despite this, reforms formation continues, which does not fully meet the characteristics and needs of the economy. In some sectors of the economy, state economic security is now increasingly focused on creating conditions for overcoming the COVID-19 pandemic with attempts to preserve the potential for future growth.

The problems of assessing the state economic security are directly interconnected with the issues of theoretical substantiation of its essence and content. The development of any economy in the face of intensified global competition, globalization of financial flows, and excessive money supply are significantly limited. Kozmenko and Korneev (2014) concluded that the harmonious regulation of the financial and real sectors of the economy in its financialization is the basis for the sustainable development of economic processes in a country. D'yakonova et al. (2018) profoundly investigated methodological bases for the efficiency assessment of economic security management of the enterprises in the global environment.

Isroilov et al. (2020) used a system of determinants, such as budget revenues and income, inflation, external debt, and unemployment, to evaluate social, economic, financial, political, environmental, and epidemiological situations. The study admitted general negative tendentious to strengthen economic security considering the Covid-19 pandemic. Frolov et al. (2017) drew attention to the support of small businesses, the sustainable development of which is the key to the state economic revival. It was noted that the development of the economic environment is influenced by negative economic factors and insufficient state financial and legal support, which is the basis for the development of the shadow economy. This, in turn, reduces the economic security of the state. In addition, Bulatova et al. (2020) characterized the influence of global financial transformation. The correlation between global and regional financial trends was identified, which shaped CEE countries' economic security and revealed their economic security shifts. Gryshova et al. (2020) used a similar approach. As the basis for assessing the economic security of the state, they identified a hierarchically structured system of determinants, which includes a set of composite, complex, and sub-determinants. The study assessed the level of economic security based on international indices and rankings. They identified government concerns to improve economic security, which should become a priority, based on the analysis of the correlation between the level of GDP per capita and individual determinants of the compositional determinant of economic security. At the same time, these concerns could increase the GDP and ensure the sustainable development of the European Union. Thus, Kozmenko and Savchenko (2013) outlined the procedure for calculating the value of the equilibrium of GDP in the formation of policy rules. The multifactor regression model confirmed a statistically significant relationship between the basic parameters of the monetary rule. This can become one of the main tools for developing and implementing monetary policy, the stable development of which is the key to the economic security of the state. 
The index method is widely used to ensure the state economic security. For example, Ignatov (2019) studied the main subversive determinants that threatened the prospects of the European Union in the period 2007-2017 since they had an impact on its economic security. The calculation by countries of aggregate average scores of such parameters as debt, real GDP growth, fixed capital investment, productivity, technology, and institutional indicators, allowed conducting an overall assessment of the dynamics of economic security of the European Union. The main factor influencing the economic security of the state was outlined - the growth rate of real GDP as a macroeconomic indicator that shows the evolution of economic production of the country, excluding the impact of inflation or deflation. Cherniavskyi et al. (2021) used similar methods and admitted that ensuring economic security guarantees stable state growth and improves the welfare of the population. To ensure the economic security of Ukraine, a comparative legal analysis was made and a proposal to implement the positive experience of EU countries was identified. In turn, Hnatenko (2021) substantiated the essence and generalized the assessment results of the main factors that influence the economic security of the state. It was mentioned that neglecting economic security could lead to negative socio-economic consequences, a depressed state of the economic branches, increased import dependence level, the bankruptcy of market participants, etc.

As for the methodological approach, there are many models for the analysis of state economic security determinants. Using such multivariate data analysis methods as principal components analysis, level of development, canonical correlation, error correction model, and vector autoregression technology, Guryanova et al. (2017) presented a systematic approach to assess the dynamics of financial security determinants. They selected the most sensitive to external shocks financial security subsystems, as well as sources of threat occurrence. To identify threats and prevent their negative impact, it was proposed to use a set of models, which were identified as the basis of the forecasting and analytical mechanism of the financial security system. As a component of economic security, Haber et al. (2018) studied the financial security of a country. This approach allows the use of the most important determinants, which makes it possible to outline measures to prevent existing threats. Based on a regression analysis of the determinants of influence relevant to the financial component of economic security as a critical element in ensuring sustainable financial development of a country, it was possible to forecast the level of financial security of a country. At the same time, Reutov et al. (2018) determined threats and destabilizing determinants in advance of a comprehensive system of financial security determinants and threshold values. However, it should be noted that when calculating the level of financial security, the implicit use of methods and compliance with guidelines is insufficient for a comprehensive analysis of the financial security of the state. Kolodiziev et al. (2018) identified the causes of the spread of crisis trends and justified the most effective levers of regulatory influence on the parameters of the banking system, as well as analyzed causations. Using a binary logit model, Kozmenko and Belova (2015) found a functional relationship between the crisis in the economy and the activities of systemically important banks. At the same time, Boța-Avram et al. (2018) used similar methods to identify a two-way causal link between components such as country-level governance, economic growth, and sustainable development. This was done to draw attention to the relationship between country-level management and economic growth, on the one hand, and between country-level government and adjusted net savings, as a selected determinant of sustainable economic development, on the other hand. In addition, Hryhoruk et al. (2019) designed the scientific and systematic approach of the economic security composite index. They identified its level based on the double use of Harrington's desirability scale. This proposed approach can be used for another set of partial determinants to assess financial security at the national level.

Systematization of methods to evaluate the state economic security shows that one of the main tasks is to substantiate the criteria and choose a system of their threshold values. State economic security depends on social, economic, financial, political, environmental, and epidemiological conditions. 


\section{AIM, DATA, AND METHODOLOGY}

This study aims to identify possible links between leading determinants of state economic security based on causal analysis of effective public administration.

For the analysis, 18 determinants were selected, which characterize the level of international economic and social development of Ukraine (Table 1). The determinants dynamics are considered in quarterly terms from the first quarter of 2014 to the fourth quarter of 2020 (Table A1). Although most scientists have described 2014 as a year of economic uncertainty, it has been found that this period does not affect the overall quality of the model.

Table 1. Input data for causal analysis of state economic security determinants

\begin{tabular}{|c|c|c|}
\hline \multicolumn{2}{|r|}{ Determinant } & \multirow{2}{*}{$\frac{\text { Code }}{\text { GDP }}$} \\
\hline 1 & Real GDP & \\
\hline \multicolumn{3}{|c|}{ International economic development determinants } \\
\hline 2 & Exports of goods and services, real value & EXP \\
\hline 3 & Imports of goods and services, real value & IMP \\
\hline 4 & $\begin{array}{l}\text { Balance of payments (current account), } \\
\text { goods and services, net }\end{array}$ & BAL_PMNT_CA \\
\hline 4 & Balance of payments (financial statement) & BAL_PMNT_FA \\
\hline 6 & $\begin{array}{l}\text { International liquidity (total reserves, } \\
\text { except gold) }\end{array}$ & IL_TR \\
\hline
\end{tabular}

\begin{tabular}{|c|c|c|}
\hline \multicolumn{2}{|r|}{ Determinant } & Code \\
\hline 7 & International funds (official reserve assets) & IL_ORA \\
\hline 8 & Global liquidity (gold) & IL_GOLD \\
\hline 9 & Changes in world trade & WT_\% \\
\hline 10 & The shift in industry volume (world) & IV_\% \\
\hline 11 & Trade policy uncertainty index & TRP_UN_I \\
\hline 12 & Geopolitical risks index & GEO_I \\
\hline \multicolumn{3}{|c|}{ Social development determinants } \\
\hline 13 & $\begin{array}{l}\text { Household consumption expenditures } \\
\text { (actual) }\end{array}$ & $H_{-}$CNSP_EXP \\
\hline 14 & Social benefits & SC_BNFT \\
\hline 15 & Unemployment index & UNMP_I \\
\hline 16 & $\begin{array}{l}\text { Loans for residential real estate to total } \\
\text { gross loans ratio }\end{array}$ & PR_REM \\
\hline 17 & Private remittances to Ukraine volumes & PR_INC_RATIO \\
\hline 18 & Gross fixed capital formation & GR_FXD_CAP \\
\hline
\end{tabular}

Given that the statistical data of the model have a pronounced seasonal effect, before the main calculations, it is necessary to deseasonalize the time series and select the seasonal component based on the smoothing of the series. Determinants of real GDP, exports, and imports of goods and services are presented in the calculation of real value, considering seasonal fluctuations and therefore do not require seasonal adjustment. In addition, indices (Trade Policy Uncertainty Index, Geopolitical Risk Index, and Unemployment Index) are not subject to this process.

The process of deseasonalization was carried out based on multiplicative decomposition with trend

\section{Decomposition of multiplicative time series}

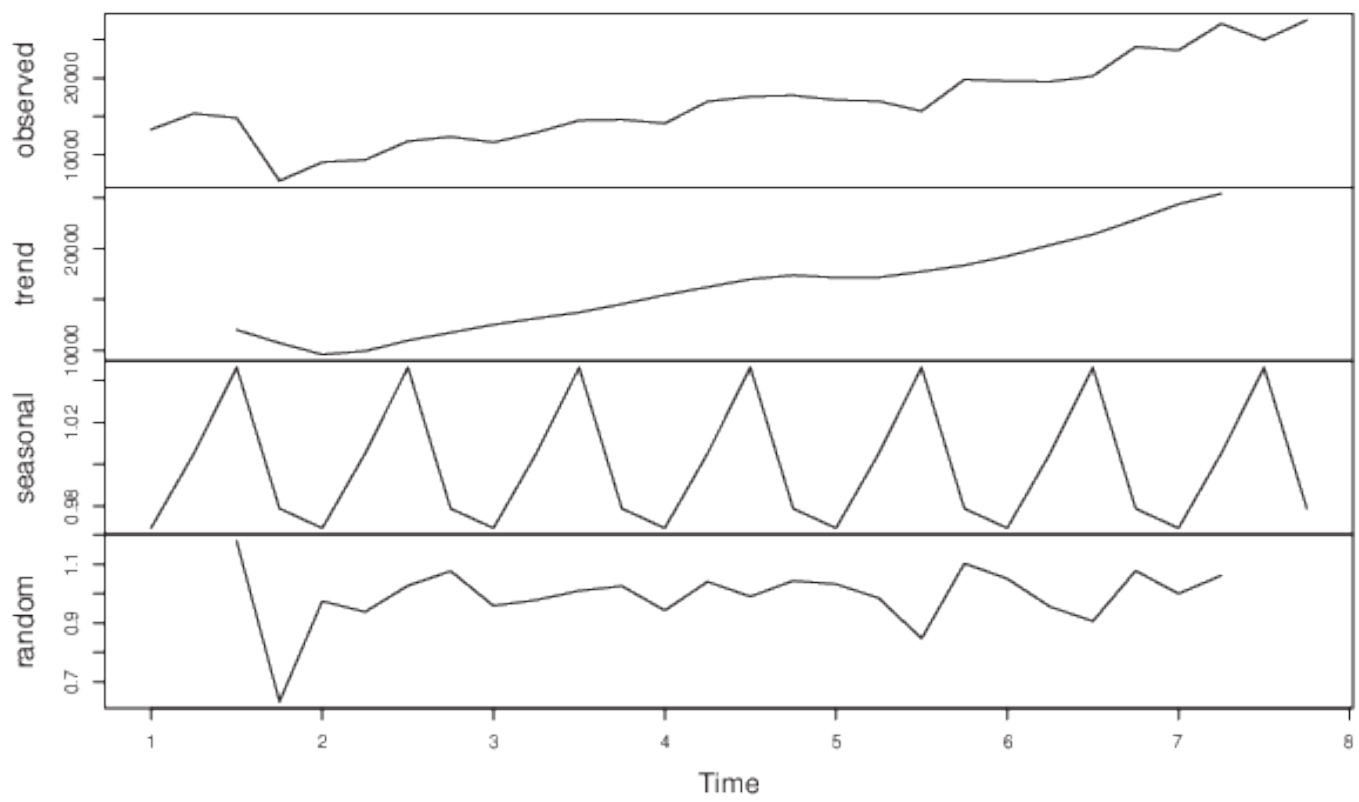

Figure 1. International liquidity (IL_TR) multiplicative time series decomposition 
smoothing. In graphical form, the results of seasonal adjustment of the time series International Liquidity $\left(I L \_T R\right)$ are presented in Figure 1.

Granger's study of causality indicates the influence of selected foreign economic and social determinants on the volume of real GDP.

As already mentioned, an essential prerequisite for the study of causality, according to Granger (1969), is the stationary time series. The most popular test for checking for stationarity is the Augmented Dickey-Fuller test. This study uses the Eviews software and the built-in Unit Root Test package to check the stationary time series of the input data.

The results of the extended Dickie-Fuller test to the input data of the model (18 determinants) allow concluding the stationarity of the time series.

The paper rejects the hypothesis of non-stationarity $I(1)$ of the following 5 determinants: EXP, IL_ORA, GEO_I, PR_INC_RATIO, and GR_FXD_CAP.

10 time series were stationary in the first differences: GDP, D_IMP, D_Bal_Pmnt_CA, D_Bal_Pmnt_ $F A, D \_I L \_T R, I L \_O R A, D \_W T \_\%, D \_I V \_\%, D_{-}$ $T r P \_U n \_I, D \_S c \_b n f t$, and $D \_U N M P \_I$.

3 time series were stationary in the second differences: $D \_D \_I L \_g o l d, D \_D \_H \_c n s p \_e x p$, and D_D_Pr_Rem.

It is optimal to check four lags, which corresponds to 4 quarters or one year. Lags number choice can be explained by the connection between the determinants characterizing the level of social and economic development of Ukraine, and the level of real GDP of the country (at a 5\% level of significance). In addition, the statistical significance of selected lags was confirmed based on the Schwartz information criterion.

\section{RESULTS}

According to Granger (1969), causality is one of the most popular concepts in econometrics. It is based on the hypothesis that the future cannot influence the past.
Granger (2001) presented this hypothesis in the information aspect. To determine whether the variable $x$ is the reason for the formation of the variable $y$, it is necessary to determine what proportion of the variance of the current value of the variable $y$ explains the previous value of the variable $y$ and whether the change of previous values of the variable $x$ variable $y$.

The variable $x$ will be the cause of $y$ if $x$ generates a prediction of $y$ from the position of decreasing variance. The results of the Granger test are presented in Figure 2.

Thus, the function built into Eviews allows testing the null hypothesis in both directions and the hypothesis that $b_{j}=0$ for $j=1$,., p. for each equation.

Based on the calculations, pairs of time series were selected between which the connection is found (Table 3).

First, the impact on the volume of real GDP is noted, with a $5 \%$ level of significance for the following determinants:

- with a lag in the 1 quarter - export of goods and services, import of goods and services;

- with a lag in 1-2 quarters - the balance of payments;

- with a lag in 3-4 quarters - international reserves, changes in world trade.

In turn, the determinants that were influenced by the volume of real GDP included:

- with a lag in the 1 quarter - international liquidity, volumes of private money transfers;

- with a lag in 1-4 quarters - unemployment index, the ratio of loans for residential real estate;

- with a lag in 3-4 quarters - index of geopolitical risks, household consumption expenditures.

A bilateral causal effect was found between the real GDP and the gross fixed capital formation with a lag in the 3 quarter. 


\begin{tabular}{|c|c|c|c|}
\hline View Proc Object Print Name Freeze) Sample Sheet Stats Spec & ec & & \\
\hline \multicolumn{4}{|l|}{$\begin{array}{l}\text { Pairwise Granger Causality Tests } \\
\text { Date: } 10 / 20 / 21 \text { Time: } 15: 55 \\
\text { Sample: } 201401202004 \\
\text { Lags: } 1\end{array}$} \\
\hline Null Hypothesis: & Obs & F-Statistic & Prob. \\
\hline $\begin{array}{l}\text { BAL_PMNT_FA does not Granger Cause BAL_PMNT_CA } \\
\text { BAL_PMNT_CA does not Granger Cause BAL_PMNT_FA }\end{array}$ & 25 & $\begin{array}{l}1.06656 \\
12.9435\end{array}$ & $\begin{array}{l}0.3129 \\
0.0016\end{array}$ \\
\hline $\begin{array}{l}\text { EXP01 does not Granger Cause BAL_PMNT_CA } \\
\text { BAL_PMNT_CA does not Granger Cause EXP01 }\end{array}$ & 27 & $\begin{array}{l}0.15372 \\
2.67219\end{array}$ & $\begin{array}{l}0.6985 \\
0.1152\end{array}$ \\
\hline $\begin{array}{l}\text { GDP does not Granger Cause BAL_PMNT_CA } \\
\text { BAL_PMNT_CA does not Granger Cause GDP }\end{array}$ & 27 & $\begin{array}{l}0.01045 \\
1.29296\end{array}$ & $\begin{array}{l}0.9194 \\
0.2667\end{array}$ \\
\hline $\begin{array}{l}\text { GEO_I does not Granger Cause EAL_PMNT_CA } \\
\text { BAL_PMNT_CA does not Granger Cause GEO_I }\end{array}$ & 27 & $\begin{array}{l}1.04374 \\
0.25042\end{array}$ & $\begin{array}{l}0.3171 \\
0.6213\end{array}$ \\
\hline $\begin{array}{l}\text { GR_FXD_CAP does not Granger Cause BAL_PMNT_CA } \\
\text { BAL_PMNT_CA does not Granger Cause GR_FXD_CAP }\end{array}$ & 27 & $\begin{array}{l}0.12358 \\
11.7963\end{array}$ & $\begin{array}{l}0.7282 \\
0.0022\end{array}$ \\
\hline $\begin{array}{l}\text { H_CNSP_EXP does not Granger Cause BAL_PMNT_CA } \\
\text { BAL_PMNT_CA does not Granger Cause H_CNSP_EXXP }\end{array}$ & 27 & $\begin{array}{l}2.13683 \\
0.00167\end{array}$ & $\begin{array}{l}0.1568 \\
0.9677\end{array}$ \\
\hline $\begin{array}{l}\text { IL_GOLD does not Granger Cause BAL_PMNT_CA } \\
\text { BAL_PMNT_CA does not Granger Cause IL_GOLD }\end{array}$ & 27 & $\begin{array}{l}0.65549 \\
0.00210\end{array}$ & $\begin{array}{l}0.4261 \\
0.9638\end{array}$ \\
\hline $\begin{array}{l}\text { IL_ORA does not Granger Cause BAL_PMNNT_CA } \\
\text { BAL_PMNT_CA does not Granger Cause IL_ORA }\end{array}$ & 27 & $\begin{array}{l}2.95981 \\
0.21497\end{array}$ & $\begin{array}{l}0.0982 \\
0.6471\end{array}$ \\
\hline $\begin{array}{l}\text { IL_TR does not Granger Cause BAL_PMNT_CA } \\
\text { BAL_PMNT_CA does not Granger Cause IL_TR }\end{array}$ & 27 & $\begin{array}{l}0.12086 \\
1.89884\end{array}$ & $\begin{array}{l}0.7311 \\
0.1809\end{array}$ \\
\hline $\begin{array}{l}\text { IMP does not Granger Cause BAL_PMNT_CA } \\
\text { BAL_PMNT_CA does not Granger Cause IMP }\end{array}$ & 27 & $\begin{array}{l}0.51894 \\
0.66117\end{array}$ & $\begin{array}{l}0.4783 \\
0.4241\end{array}$ \\
\hline $\begin{array}{l}\text { V__does not Granger Cause BAL_PMNT_CA } \\
\text { BAL_PMNT_CA does not Granger Cause V. }\end{array}$ & 27 & $\begin{array}{l}0.73493 \\
2.93922\end{array}$ & $\begin{array}{l}0.3998 \\
0.0993\end{array}$ \\
\hline
\end{tabular}

Figure 2. Granger test results (fragment)

Table 2. Statistically significant causal links

\begin{tabular}{|c|c|c|c|}
\hline Null hypothesis & Obs. & F-Statistic & Prob. \\
\hline \multicolumn{4}{|c|}{$1 \mathrm{lag}$} \\
\hline D_EXP does not Granger Cause D_GDP & 26 & 5.11289 & 0.034 \\
\hline D_GDP does not Granger Cause D_GEO_I & 26 & 5.38732 & 0.03 \\
\hline D_GDP does not Granger Cause D_GR_FXD_CAP & 26 & 4.73645 & 0.04 \\
\hline D_GDP does not Granger Cause D_IL_TR & 26 & 17.9003 & 0.0003 \\
\hline D_IMP does not Granger Cause D_GDP & 26 & 5.12004 & 0.033 \\
\hline D_GDP does not Granger Cause D_UNMP_I & 26 & 14.9209 & 0.0008 \\
\hline D_GDP does not Granger Cause D_PR_INC_RATIO & 26 & 36.0173 & 0.000004 \\
\hline D_GDP does not Granger Cause D_PR_REM & 26 & 7.99264 & 0.01 \\
\hline \multicolumn{4}{|c|}{2 lags } \\
\hline D_GDP does not Granger Cause D_BAL_PMNT_FA & 22 & 9.69999 & 0.002 \\
\hline D_GDP does not Granger Cause D_H_CNSP_EXP & 25 & 3.50497 & 0.05 \\
\hline D_GDP does not Granger Cause D_IL_TR & 25 & 5.20772 & 0.015 \\
\hline D_GDP does not Granger Cause D_UNMP_I & 25 & 4.54532 & 0.024 \\
\hline D_GDP does not Granger Cause D_PR_INC_RATIO & 25 & 13.0064 & 0.0002 \\
\hline D_GDP does not Granger Cause D_PR_REM & 25 & 5.21322 & 0.015 \\
\hline \multicolumn{4}{|c|}{3 lags } \\
\hline D_GDP does not Granger Cause D_BAL_PMNT_FA & 21 & 11.37 & 0.0005 \\
\hline D_GDP does not Granger Cause D_GEO_I & 24 & 3.3125 & 0.045 \\
\hline D_GR_FXD_CAP does not Granger Cause D_GDP & 24 & 3.31572 & 0.045 \\
\hline D_GDP does not Granger Cause D_GR_FXD_CAP & 24 & 11.0724 & 0.0003 \\
\hline
\end{tabular}


Table 2 (cont.). Statistically significant causal links

\begin{tabular}{|c|c|c|c|}
\hline Null hypothesis & Obs. & F-Statistic & Prob. \\
\hline \multicolumn{4}{|c|}{3 lags } \\
\hline D_GDP does not Granger Cause D_H_CNSP_EXP & 24 & 22.8481 & 0.000003 \\
\hline D_IL_ORA does not Granger Cause D_GDP & 24 & 4.15897 & 0.022 \\
\hline D_IV_\% does not Granger Cause D_GDP & 24 & 6.09487 & 0.005 \\
\hline D_GDP does not Granger Cause D_PR_INC_RATIO & 24 & 11.5331 & 0.0002 \\
\hline D_GDP does not Granger Cause D_PR_REM & 24 & 6.00406 & 0.006 \\
\hline \multicolumn{4}{|c|}{4 lags } \\
\hline D_GDP does not Granger Cause D_BAL_PMNT_FA & 20 & 13.7052 & 0.0003 \\
\hline D_GDP does not Granger Cause D_GEO_I & 23 & 3.45675 & 0.037 \\
\hline D_GDP does not Granger Cause D_GR_FXD_CAP & 23 & 5.15455 & 0.009 \\
\hline D_GDP does not Granger Cause D_H_CNSP_EXP & 23 & 16.9881 & 0.00003 \\
\hline D_IL_ORA does not Granger Cause D_GDP & 23 & 4.93895 & 0.011 \\
\hline D_IV_\% does not Granger Cause D_GDP & 23 & 4.97434 & 0.011 \\
\hline D_GDP does not Granger Cause D_PR_INC_RATIO & 23 & 5.08869 & 0.01 \\
\hline D_GDP does not Granger Cause D_PR_REM & 23 & 4.7567 & 0.012 \\
\hline
\end{tabular}

Table 3. Causal relationships between time series

\begin{tabular}{|c|c|c|c|c|}
\hline Null hypothesis & $1 \mathrm{lag}$ & 2 lags & 3 lags & 4 lags \\
\hline D_GDP does not Granger Cause D_BAL_PMNT_FA & - & + & + & + \\
\hline D_EXP does not Granger Cause D_GDP & + & - & - & - \\
\hline D_GDP does not Granger Cause D_GEO_I & + & - & + & + \\
\hline D_GR_FXD_CAP does not Granger Cause D_GDP & - & - & + & - \\
\hline D_GDP does not Granger Cause D_GR_FXD_CAP & + & - & + & + \\
\hline D_GDP does not Granger Cause D_H_CNSP_EXP & - & + & + & + \\
\hline D_IL_ORA does not Granger Cause D_GDP & - & - & + & + \\
\hline D_GDP does not Granger Cause D_IL_TR & + & + & - & - \\
\hline D_IMP does not Granger Cause D_GDP & + & - & - & - \\
\hline D_IV_\% does not Granger Cause D_GDP & - & - & + & + \\
\hline D_GDP does not Granger Cause D_UNMP_I & + & + & - & - \\
\hline D_GDP does not Granger Cause D_PR_INC_RATIO & + & + & + & + \\
\hline D_GDP does not Granger Cause D_PR_REM & + & + & + & + \\
\hline
\end{tabular}

It should also be noted that according to the results of calculations, no causal links were found between real GDP and the determinants balance of payments (current account), international liquidity (gold), change in the volume of industry (world), trade policy uncertainty index, and social benefits.

\section{CONCLUSION}

The study aimed to identify possible links between leading determinants of state economic security based on the causal analysis. It recognized the feature characteristics of the situation when the real GDP affects the foreign economic and social development determinants of state economic security and vice versa. In summary, 14 main determinants of state economic security affect the level of real GDP and could be managed by public administration.

For ensuring national security through economic growth, the primary efforts should be focused on developing science, technology, and education, improving domestic investment and financial institutions to achieve the required level of security in the military, defense, industrial, and international sectors. Low efficiency of state regulation of the national economy, a decrease in economic growth, the appearance of a deficit in the trade and balance of payments, and a reduction in budget revenues can lead to a slowdown in the transition to innovative development and subsequent accumulation of social problems in a country. 
Effective and transparent management of state economic security and coordination of actions of different branches of government in implementing economic reforms do not require only the selection of parameters of economic policy instruments. It is essential to build a comprehensive model that would formalize the impact of monetary, budgetary, tax, etc., components of state economic security on sectors of the economy, develop a forecast of significant macroeconomic changes, and conduct a qualitative analysis. A causal analysis of state economic security adequately reflects the current economic situation. It is quite simple and clear to apply for both scientists and all public officials.

\section{AUTHOR CONTRIBUTIONS}

Conceptualization: Volodymyr Orlov, Marcin Marczuk.

Data curation: Alina Bukhtiarova, Mykhaylo Heyenko.

Formal analysis: Alina Bukhtiarova, Mykhaylo Heyenko.

Methodology: Volodymyr Orlov, Marcin Marczuk.

Project administration: Volodymyr Orlov, Marcin Marczuk.

Supervision: Volodymyr Orlov, Marcin Marczuk.

Validation: Volodymyr Orlov, Marcin Marczuk.

Visualization: Alina Bukhtiarova, Mykhaylo Heyenko.

Writing - original draft: Alina Bukhtiarova, Mykhaylo Heyenko.

Writing - reviewing \& editing: Volodymyr Orlov, Alina Bukhtiarova.

\section{ACKNOWLEDGMENT}

Alina Bukhtiarova gratefully acknowledges financial support from the Ministry of Education and Science of Ukraine (0120U100473).

\section{REFERENCES}

1. Boța-Avram, C., Groșanu, A., Răchişan, P-R., \& Gavriletea, M. D. (2018). The Bidirectional Causality between Country-Level Governance, Economic Growth and Sustainable Development: A Cross-Country Data Analysis. Sustainability, 10(2), 502. https://doi. org/10.3390/su10020502

2. Bulatova, O., Marena, T., Chentukov, Yu., \& Shabelnyk, T. (2020). The impact of global financial transformations on the economic security of Central and Eastern European countries. Public and Municipal Finance, 9(1), 1-13. http://dx.doi. org/10.21511/pmf.09(1).2020.01

3. Cherniavskyi, S., Dzhuzha, O., Babanina, V., \& Harust, Y. (2021). System of ensuring the economic security of the state: world experience and ways of its reform in Ukraine. Journal of Gender and Interdisciplinarity, 2(01). Retrieved from https://periodicojs.com.br/ index.php/gei/article/view/132
4. Cofase for Trade. (n.d.). Ukraine Economic studies. Retrieved from http://www.coface.com/EconomicStudies-and-Country-Risks/ Ukraine

5. D'yakonova, I., Nikitina, A., Sukhonos, V., \& Zhuravka, F. (2018). Methodological bases of estimating the efficiency of economic security management of the enterprises in the global environment. Investment Management and Financial Innovations, 15(2), 145-153. http://dx.doi. org/10.21511/imfi.15(2).2018.13

6. Edwards, R. W. (2007). Financial Soundness Determinants: Experience with the Coordinated Compilation Exercise and Next Steps: Background Paper (IMF Working Paper 101807). Washington: International Monetary Fund. Retrieved from http://www.imf.org/external/pubs/ ft/weo/2008/02/pdf/text.pdf

7. Frolov, S., Strilec, V., \& Balatskyi, I. (2017). Foresight technologies in financial provision of small business in Ukraine. Problems and Perspectives in Management, 15(1-cont.),
200-209. https://doi.org/10.21511/ ppm.15(1-1).2017.07

8. Granger, C. W. J. (1969). Investigation Casual Relations by Econometric Methods and Cross-Spectal Methods. Econometrica, 37(3), 424-438. https://doi. org/10.2307/1912791

9. Granger, C. W. J. (2001). Essays in Econometrics: The Collected Papers of Clive W. J. Granger. Cambridge: Cambridge University Press.

10. Gryshova, I., Kyzym, M., Hubarieva, I., Khaustova, V., Livinskyi, A., \& Koroshenko, M. (2020). Assessment of the EU and Ukraine economic security and its influence on their sustainable economic development. Sustainability, 12(18), 7692. https:// doi.org/10.3390/su12187692

11. Guryanova, L., Klebanova, T., Milevskiy, S., Nepomnyaschiy, V., \& Rudachenko, O. (2017). Models for the analysis of the state's financial security determinants dynamics. Financial and credit activity: problems of theory and practice, 1(22), 254-264. 
12. Haber, J., Bukhtiarova, A., Chorna, S., Iastremska, O., \& Bolgar, T. (2018). Forecasting the level of financial security of the country (on the example of Ukraine). Investment Management and Financial Innovations, 15(3), 304-317. http://dx.doi. org/10.21511/imfi.15(3).2018.25

13. Hnatenko, V. (2021). Key factors of the state's economic security. Public Administration and Law Review, 1 , 61-66. Retrieved from https://public. scnchub.com/palr/index.php/palr/ article/view/72

14. Hryhoruk, P., Khrushch, N., \& Grygoruk, S. (2019). Model for assessment of the financial security level of the enterprise based of the desirability scale. SHS Web of Conferences, 65. https://doi.org/10.1051/ shsconf/20196503005

15. Ignatov, A. (2019). Analysis of the dynamics of the European economic security in the conditions of a changing socio-economic environment. New Medit, 18(2), 15-56. http://dx.doi.org/10.30682/ nm1902b

16. Isroilov, B., Ibragimov, B. B., Pardaev, K., \& Ibragimov, B. J. (2020). Economic Security: Threats, Analysis and Conclusions. International Journal of Multicultural and Multireligious Understanding, 7(8). http://dx.doi.org/10.18415/ijmmu. v7i8.1806

17. Kolodiziev, O., Chmutova, I., \& Lesik, V. (2018). Use of causal analysis to improve the monitoring of the banking system stability. Banks and Bank Systems, 13(2), 62-76. https:// doi.org/10.21511/bbs.13(2).2018.06

18. Kozmenko, S., \& Belova, I. (2015). Peculiarities of identification of systemically important banks and assessment of their impact of the occurrence of economic crisis. Banks and Bank Systems, 10(3), 39-48. Retrieved from https://www.businessperspectives.org/images/pdf/applications/publishing/templates/article/ assets/6909/BBS_en_2015_03_Kozmenko.pdf

19. Kozmenko, S., \& Korneev, M. (2014). Periodization of financialization process of economics: Domestic and foreign contexts. Economic Annals-XXI, 9-10(1), 73-76. Retrieved from http://soskin.info/ userfiles/file/2014/9-10_2014/1/

Kozmenko,Korneev.pdf

20. Kozmenko, S., \& Savchenko, T. (2013). Development of an explicit rule of monetary policy for the economy of Ukraine. Investment Management and Financial Innovations, 10(1), 8-19. Retrieved from https://www.businessperspectives.org/index.php/journals/ investment-management-andfinancial-innovations/issue-90/ development-of-an-explicit-rule-ofmonetary-policy-for-the-economyof-ukraine

21. Ostapiuk, N., Karmaza, O., Kurylo, M., \& Timchenko, G. (2017). Economic security in investment projects management: convergence of accounting mechanisms. Investment Management and Financial Innovations, 14(3), 353-360. http://dx.doi. org/10.21511/imfi.14(3-2).2017.06

22. Reutov, V., Burkaltseva, D., Blazhevich, O., Borsch, L., Gabrielyan, O., Khlybova, N., \& Guk, O. (2018). The Method of Assessing the State's Financial Security Level. International Journal of Engineering and Technology, 7(3), 404-411. Retrieved from https://www.researchgate.net/ publication/327682095_The_Method_of_Assessing_the_State $\% 27 \mathrm{~s}$ Financial_Security_Level

23. Sytnyk, H. (2017). Preliminary assessment of implementing the economic part of the National Security Strategy of Ukraine. Problems and Perspectives in Management, 15(4), 24-37. http://dx.doi.org/10.21511/ ppm.15(4).2017.03

24. Thakolsri, S. (2021). Modeling the relationships among gold price, oil price, foreign exchange, and the stock market index in Thailand. Investment Management and Financial Innovations, 18(2), 261-272. https:// doi.org/10.21511/imfi.18(2).2021.21

25. The Ministry of Economy of Ukraine. (n.d.). Metodychni rekomendatsii shchodo rozrakhunku rivnia ekonomichnoi bezpeky Ukrainy [Methodical recommendations for calculating the level of economic security of Ukraine]. (In Ukrainian). Retrieved from https://www.me.gov. ua/Documents/List?lang=ukUA\&id $=\mathrm{d} 4 \mathrm{c}$ c96730-ea46-4ebd-ba9260631a3e2e69\&tag=MetodichniRek omendatsiiMakroekonomika\&isSp ecial=true
26. The Ministry of Finance. (2021). Vykonannia Derzhavnoho Biudzhetu Ukrainy [Determinants of implementation of the State Budget of Ukraine]. (In Ukrainian). Retrieved from https://index.minfin.com.ua/ ua/finance/budget/gov/2021/

27. The National Bank of Ukraine. (2021). Hroshovo-kredytna statystyka [Monetary statistics]. (In Ukrainian). Retrieved from https:// bank.gov.ua/ua/news/all/groshovokreditna-ta-finansova-statistikasichen-2021-roku

28. The National Bank of Ukraine. (n.d.). Statystyka indykatoriv finansovoi stiikosti - formy zvitnosti [Statistics of financial stability indicators - Reporting forms]. (In Ukrainian). Retrieved from http://www. bank.gov.ua/control/uk/publish/ category?Cat_id=44575

29. The State Statistics Service of Ukraine. (n.d.). Statystychna informatsiia pro VVP ta indeks spozhyvchykh tsin [Statistical information on GDP and the consumer price index]. (In Ukrainian). Retrieved from http://www.ukrstat. gov.ua

30. Voznyak, H., Mulska, O., Kloba, T., \& Kloba, L. (2021). Assessing and strengthening budgetary security of regions and their amalgamated hromada in an unstable economy: A case for Ukraine. Public and Municipal Finance, 10(1), 138-150. https:// doi.org/10.21511/pmf.10(1).2021.11

31. Wessa, P. (2021). Free Statistics and Forecasting Software. Retrieved from http://www.wessa.net/rwasp_decompose.wasp/

32. Yasynska, N., Syrmamiikh, I., \& Penez, O. (2021). Monitoring the financial security of the Ukrainian banking sector in the context of system deterministic challenges. Banks and Bank Systems, 16(2), 12-26. https://doi.org/10.21511/ bbs.16(2).2021.02 
APPENDIX A

Table A1. Input data for causal analysis of state economic security determinants

\begin{tabular}{|c|c|c|c|c|c|c|c|c|c|c|c|c|c|c|c|c|c|c|}
\hline & GDP & EXP & IMP & 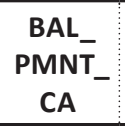 & $\begin{array}{c}\text { BAL_- } \\
\text { PMNT__ } \\
\text { FA }\end{array}$ & IL_TR & IL_ORA & IL_GOLD & WT_\% & IV_\% & $\begin{array}{l}\text { TRP_ } \\
\text { UN_I }\end{array}$ & GEO_I & $\begin{array}{c}\text { H_CNSP } \\
\text { EXP }\end{array}$ & SC_BNFT & UNMP_I & PR_REM & $\begin{array}{l}\text { PR_INC } \\
\text { RATIO }\end{array}$ & $\begin{array}{c}\text { GR_FXD_ } \\
\text { CAP }\end{array}$ \\
\hline 2014Q1 & 686595 & 385089 & 406445 & -1258 & -2 & 13316.27 & 16.06 & 1769.26 & 2.1 & 3.5 & 27 & 310 & 460079 & 9.40 & 5.75 & 1547 & 7.9 & 73973 \\
\hline 2014Q2 & 658887 & 371329 & 405197 & -742 & 1 & 15386.03 & 6.26 & 1697.28 & 2.9 & 3.4 & 28 & 279 & 474996 & 9.00 & 6.04 & 1686 & 8.3 & 77174 \\
\hline 2014Q3 & 629195 & 330605 & 334824 & -956 & 1 & 14816.51 & 1.11 & 1568.73 & 4.5 & 3.3 & 20 & 286 & 482918 & 9.30 & 6.3 & 1778 & 8.8 & 81989 \\
\hline 2014Q4 & 606067 & 292289 & 326021 & -1650 & 1 & 6622.24 & 3.74 & 911.09 & 4.3 & 3.1 & 29 & 246 & 507014 & 9.70 & 6.68 & 1478 & 8.2 & 103976 \\
\hline 201501 & 587734 & 302569 & 333209 & -660 & 1 & 9058.61 & 5.59 & 911.31 & 2.5 & 1.9 & 21 & 236 & 368591 & 10.00 & 7.73 & 1482 & 12.5 & 56401 \\
\hline $2015 Q 2$ & 578056 & 305926 & 304005 & -241 & 2 & 9356.93 & 5.53 & 906.77 & 2.6 & 2 & 45 & 252 & 348058 & 9.60 & 6.12 & 1769 & 11.2 & 66231 \\
\hline $2015 Q 3$ & 581667 & 305443 & 296961 & -579 & 2 & 11783.77 & 5.92 & 989.78 & 0.7 & 1.5 & 29 & 289 & 392115 & 9.40 & 5.97 & 1840 & 10.7 & 77915 \\
\hline $2015 Q 4$ & 581071 & 283784 & 292819 & -882 & 4.6 & 12368.08 & 8.82 & 931.91 & 1.1 & 0.5 & 32 & 208 & 438377 & 9.50 & 6.32 & 1868 & 8.6 & 105570 \\
\hline 2016Q1 & 590087 & 289637 & 326394 & -1772 & -0.5 & 11631.44 & 1.39 & 1090.07 & 0.6 & 1.4 & 54 & 185 & 363251 & 10.30 & 6.26 & 1572 & 9.3 & 59440 \\
\hline 2016Q2 & 592988 & 290613 & 315164 & -562 & -0.1 & 12914.06 & 1.81 & 1067.64 & 1.6 & 1.6 & 75 & 122 & 363303 & 9.80 & 6.12 & 1885 & 9.1 & 78206 \\
\hline 2016Q3 & 597449 & 291348 & 349831 & -2298 & -1.3 & 14495.59 & 2.87 & 1093.15 & 1.5 & 1.6 & 44 & 198 & 412090 & 9.60 & 5.68 & 2053 & 8.8 & 96600 \\
\hline 2016Q4 & 604843 & 304355 & 349726 & -1821 & -3.1 & 14597.62 & 2.70 & 941.71 & 3.6 & 3.4 & 106 & 225 & 449957 & 9.70 & 5.59 & 2025 & 6.9 & 134445 \\
\hline 2017Q1 & 603978 & 306262 & 367033 & -1380 & -4.2 & 14102.06 & 2.65 & 1021.24 & 6.6 & 3.3 & 91 & 191 & 383431 & 10.50 & 5.32 & 1925 & 7.1 & 70258 \\
\hline 2017Q2 & 607892 & 300076 & 371307 & -1766 & -4.6 & 16954.02 & 3.16 & 1017.18 & 4.4 & 3.7 & 60 & 160 & 406669 & 10.00 & 5.06 & 2262 & 7 & 94687 \\
\hline $2017 Q 3$ & 614552 & 306592 & 378188 & -2736 & -4.8 & 17591.86 & 2.76 & 1045.62 & 5.4 & 3.9 & 51 & 200 & 442696 & 9.70 & 4.74 & 2466 & 6.6 & 108953 \\
\hline 2017Q4 & 617769 & 307241 & 393494 & -2862 & -6 & 17747.80 & 2.17 & 1060.65 & 5 & 4.1 & 47 & 202 & 503965 & 9.90 & 4.45 & 2611 & 5.5 & 154021 \\
\hline 2018Q1 & 625007 & 297054 & 374989 & -1890 & -7.3 & 17154.11 & 1.56 & 1037.79 & 2 & 3.9 & 261 & 209 & 415494 & 10.00 & 3.98 & 2571 & 6 & 85856 \\
\hline 201802 & 628465 & 305686 & 390168 & -1982 & -6.3 & 16993.06 & 0.91 & 985.51 & 3.6 & 3 & 229 & 208 & 436265 & 9.30 & 3.84 & 2714 & 6 & 113461 \\
\hline $2018 Q 3$ & 632826 & 293426 & 391730 & -4247 & -5.6 & 15700.10 & 0.30 & 937.59 & 2.5 & 2.6 & 150 & 185 & 496382 & 9.00 & 4.19 & 2865 & 6.1 & 125373 \\
\hline 2018Q4 & 641125 & 308288 & 398329 & -3259 & -9.3 & 19818.21 & 3.53 & 1002.22 & -1.2 & 1.6 & 165 & 249 & 550417 & 9.10 & 3.83 & 2961 & 5 & 174220 \\
\hline 201901 & 648325 & 319901 & 399160 & -1865 & -8.5 & 19605.96 & 1.69 & 1026.91 & 1.6 & 2.3 & 94 & 201 & 462147 & 9.60 & 3.79 & 2678 & 5.1 & 97481 \\
\hline $2019 Q 2$ & 656836 & 325807 & 432442 & -2923 & -9.3 & 19532.68 & 5.88 & 1106.29 & -0.9 & 1.1 & 266 & 186 & 492347 & 8.80 & 3.62 & 2898 & 5.5 & 118127 \\
\hline 201903 & 655567 & 327618 & 412985 & -4168 & -13.2 & 20258.62 & 12.33 & 1179.19 & -0.8 & 0.5 & 137 & 150 & 543478 & 8.40 & 3.43 & 3125 & 5.7 & 138561 \\
\hline 2019Q4 & 648115 & 319417 & 399622 & -3555 & -10.1 & 24083.37 & 9.87 & 1218.79 & -0.1 & 0.7 & 146 & 159 & 608166 & 8.60 & 3.1 & 3220 & 4.7 & 203255 \\
\hline $2020 Q 1$ & 640601 & 313211 & 385274 & -1148 & -7 & 23610.31 & 7.49 & 1313.44 & -5.1 & -4.4 & 61 & 169 & 501363 & 8.90 & 3.23 & 2873 & 5.2 & 77039 \\
\hline 202002 & 586178 & 298485 & 345024 & 796 & -4.6 & 27085.23 & 1.47 & 1429.97 & -9.2 & -7.1 & 60 & 222 & 442927 & 9.60 & 3.28 & 2740 & 5.8 & 90935 \\
\hline $2020 Q 3$ & 635981 & 308096 & 373969 & -1113 & 2.7 & 24975.95 & 6.13 & 1549.8 & -1.5 & -1.7 & 68 & 203 & 552158 & 9.70 & 3.37 & 3115 & 5.6 & 103842 \\
\hline 2020Q4 & 641199 & 300623 & 381666 & -973 & 3.2 & 27549.02 & 4.52 & 1583.87 & 1.2 & 1.1 & 98 & 166 & 639847 & 9.90 & 2.92 & 3160 & 4.6 & 149353 \\
\hline
\end{tabular}

